\title{
LEXICON
}

Volume 6, Number 2

October 2019

https://jurnal.ugm.ac.id/lexicon

Pages 218-227

\section{A Comparative Study of Apology Strategies produced by Indonesian and Australian Bridge Players}

\author{
Fanny Misfa Jessy, Thomas J.P. Sembodo* \\ English Department, Universitas Gadjah Mada, Indonesia \\ *Corresponding Author: thomassembodo@ugm.ac.id
}

\section{ABSTRACT}

\begin{abstract}
This study aims to identify, classify, and compare the apology strategies used by Indonesian and Australian bridge players. The data were gathered from 10 Indonesian bridge players and 10 Australian bridge players through a Discourse Completion Task (DCT) questionnaire. There are 173 apology strategies found among Indonesian bridge players and 146 apology strategies among Australian bridge players. The data are classified by the categorization adapted from previous research such as Cohen and Olshtain (1981), Blum-Kulka and Olshtain (1984) and Shahrokhi and Jan (2012). The result of the study shows some similarities and differences in terms of frequency of apology strategies used by Indonesian and Australian bridge players. The findings of this study describe the speech acts of apology between two groups of people with different cultural backgrounds.
\end{abstract}

Keywords: Apology strategies, Australian, bridge players, Indonesian, level of offense.

\section{INTRODUCTION}

People use an apology when they realize that they have made a mistake. However, people might have different preferences whether, when and how to apologize. People can apologize by simply saying "I apologize" or "I regret", or, moreover, they can express their regret by, for example, repairing the mistakes they have made, or taking responsibility for what they did.

The strategies of apology are discussed in the field of Pragmatics especially in speech act theory. There have been many studies on apology strategies and one of the popular research was conducted by Blum-Kulka and Olshtain (1984). In their work, Blum-Kulka and Olshtain (1984) used Cross-
Cultural Study Speech Act Realization Patterns (CCSARP) as their data analysis. CCSARP is considered to have a universality to analyze crosslinguistic comparisons that have cross-cultural diversity. According to Blum-Kulka and Olstain (1984), the project is expected to be able to provide a further understanding of speech acts especially requests and apologies.

In the field of sports, there are some situations when players have to apologize. One of the sports that is recently well-known is Bridge sports. Bridge is a card game played in pairs or groups. This game has developed in various countries around the world, such as Indonesia and Australia. Having experience as a bridge player, the researcher of the current study is interested to observe whether there 
are differences or similarities in apology strategies used by bridge players from Indonesia and Australia.

\section{LITERATURE REVIEW}

There have been many pragmatic studies about apology strategies. Demeter (2000), for example, investigated apology strategies used in Romanian using a Discourse Completion Task (DCT) to collect their data. He got 150 respondents producing 1,500 strategies to analyze. The findings prove that the Romanian speakers that participated in the survey overwhelmingly preferred to use more than one category when apologizing.

Shahrokhi and Jan (2012) examined the realization of apology strategies among Persian males. The research focuses on investigating the apology speech act by Persian male native speakers to categorize and formulate the apology strategies employed in their interactions in various social contexts. In their research, they also use the coding scheme of CCSARP (Cross-Cultural Speech Act Realization Patterns) by Blum Kulka and Olshtain (1989) with some modification to analyze the data collected. The result of his study shows that the high frequency of IFID (Illocutionary Force Indicating Device) as the most frequent and direct way of apologizing reflects Persian's orientation toward the negative politeness. However they also stated that the analysis of the data of this study may not be generalized to all Persian males community; but still, it can provide some insights on the apology strategy patterns in the Persian male context and some of the implications on cultural norms and rules in the Persian society.

Subandi (2014) explored the use of crosscultural politeness strategies of apologies by Australian English speakers and Indonesian speakers. The research reveals the respondents use different strategies when producing apology speech acts. Indonesian speakers tend to respect age and social class in realizing apology, also they mostly use more vary strategies and longer sentences. Meanwhile, Australian were more likely to ignore age or social status.
Another research is "Apology strategies and gender: A Pragmatic Study of apology speech acts in the Urdu language" by Majeed and Janjua (2014). They researched by collecting data through DCT which was used in CCSARP by Blum Kulka, 1982. The data were analyzed using a coding procedure developed by the CCSARP with some modifications. They focus on an apology strategy in the Urdu language conducted by the students at the National University of Modern Languages Islamabad. The results of the research indicate that the gender differences emerging are influenced by their social position and authority and the female participants seem to be more aware of their facial desires when negotiating with their friends and relatives.

\section{THEORETICAL FRAMEWORK}

Morris (1938) signifies pragmatics as a relation between signs and the people who interpret it. According to Morris (1938) pragmatics is the study of speech acts which linguistically conveys a sign that contains meaning (p. 30). The focus of this study is to classify the apology strategies used by two different groups of people. Therefore, it applies several theories related to the topic of this research.

The first is context. It is an action about "understanding what things are for; it is also what gives our utterances their true pragmatic meaning and allows them to be counted as true pragmatic acts" (Mey, 2001, p. 41). According to Cutting (2002), there are three types of context; situational context, background knowledge context, and cotextual context. Situational context is what speakers know about what they can see around them. Background knowledge context is what they know about each other and the world. Lastly, co-textual context is what they know about what they have been saying.

The action in conveying what is intended by the speaker to the hearer is done through utterances. Utterance is 'a term used in linguistics and phonetics to refer to a stretch of speech about which no assumptions have been made in terms of linguistic theory' (Crystal, 2008, p. 505). Bowe et al. (2014) point out that a speech act is concerned with understanding the intentions and conventions 
linked to an utterance and what this utterance can do.

According to Austin (1962) and Searle (1969) an utterance consists of three components. First is locution, the actual form of the utterance. It is the basic production of the meaningful utterance of what is said. This component is more related to the hearer. If the hearer fails to understand what the speaker is saying then the speaker has failed to do a locutionary act. The second is illocution, the communicative force of the utterance. It is what is intended by the speaker in making the utterance. An illocutionary act is accomplished via utterance with a communicative intention. A speaker may perform an illocutionary act to make a promise, offer or explanation as proposed by Austin (1962) as an illocutionary force. The third is perlocution, the communicative effect of the utterance. This act is about producing the effect of meaningful, intentional utterance. It is what the hearer interprets as the meaning intended by the utterance.

Searle (1976) conveys that illocutionary act is the basic unit of human linguistic communication. It relates to the speaker's purposes by uttering sentences. There are five kinds of speech acts adapted from Searle (1976, p. 16-21):

1) Representatives, e.g. affirm, deny, report, believe, etc.

2) Directives, e.g. command, request, insist, ask, etc.

3) Commissives, e.g. promise, offer, declare, etc.

4) Expressives, e.g. 'thank', 'congratulate', 'apologize', 'condole', 'deplore', and 'welcome'.

5) Declarations, e.g. baptize, name, appoint, etc.

Apology comes under expressive speech acts. Cohen and Olshtain (1981) perceive apology as a social event when they point out that it is performed when social norms are violated. Cohen and Olshtain (1981, p. 113-134) state that there are six types of apology strategies as follows;

a) Illocutionary force indicating devices (IFID)

- An expression of regret, e.g. I'm sorry.

- An offer of apology, e.g. I apologize.

- A request for forgiveness, e.g. Forgive me

b) Taking responsibility (TOR)

- Explicit self-blame, e.g. It is my fault.
- Lack of intent, e.g. I didn't mean it.

- Expression of self-deficiency, e.g. I forgot.

- Self-dispraise, e.g. I'm such a fool!

- Justify hearer, e.g. You're right.

- Refusal to acknowledge guilt, e.g. It wasn't my fault.

- Statement of the Offense (STO), e.g. I didn't bring your book

c) An explanation or account of the situation (AES), explaining the reasons for the violation, e.g. The traffic was terrible.

d) An offer of repair (AOR), e.g. I'll pay for it.

e) A promise for forbearance (POF), e.g. It won't happen again.

f) Concern for the Hearer (CFH), e.g. Are you okay?

Another strategy is shown in Shahrokhi and Jan (2012) research. Shahrokhi and Jan (2012, p. 695) state that the respondents in their research occasionally underestimated the offense as humor to reduce the frequency of the offensethey were responsible for in some situations explained in the DCT.

Felicity conditions, according to Crystal (2008), refer to the conditions that must be in place and the criteria that must be satisfied for a speech act to achieve its purpose. In other words, it is a criterion that must be fulfilled if the speech act wants to reach its purpose. Murphy (2015) summarizes that there are four types of felicity conditions, which can cover most of the utterances described as apology speech acts, as follows:

Propositional content: an act is done, or to be done in the future, by the speaker or someone for whom the speaker is a formally recognized representative.

Preparatory condition: speaker believes that the apology recipient, or a contextually relevant third party, believes that the act was an offense against the recipient (or someone whom the recipient represents).

Sincerity condition: speaker regrets the act of one of its consequences.

Essential condition: utterance counts as an apology. (pp. 10-11) 


\section{METHODS}

\section{Participants}

The subjects of the study are divided into two groups. The first group consists of ten young bridge players from Indonesia. This group answered the question in Indonesian. The second group are ten young bridge players from Australia. The researcher recruited the Australian bridge athletes from a bridge application named Bridge Base Online. This group answered the question in English. All participants are in the age range of 20 - 26 years old.

\section{Method of Data Collection}

The current study employed a Discourse Completion Test (DCT) for data collection. Many pragmatics studies about apology strategy use the DCT to investigate variation in the validity of crosscultural speech acts. The DCT used in this research is adapted from the DCT in the research conducted by Shahrokhi and Jan (2012). The situations are adjusted to the possible incidents that happen in a bridge game. Participants were asked to imagine themselves in the described situations and to respond accordingly.

\section{Method of Data Analysis}

This study aims to analyze and compare the speech acts of apology employed by Indonesian and Australian bridge players. After the data has been collected, the researcher code the data from each participant and categorized each group's responses by the situations using the coding scheme of $\mathrm{A}$ Cross-Cultural Study of Speech Act Realization Pattern (CCSARP) project and compared the results. The use of cross-cultural study is to compare the practice of communication from one language / cultural group to another, as used in previous studies. After coding was completed, the frequency of distributions of apology strategies by the participants was calculated. Finally, the apology realization patterns of the Indonesian bridge players were compared to those of Australian bridge players to identify any similarities and differences between the two groups.

\section{RESULTS AND DISCUSSION}

There are a total of 173 apologies produced by Indonesian bridge players. IFID was used 74 times by Indonesian bridge players. Expression of regret was produced twice $(1,16 \%)$, an offer of apology was spoken 68 times $(39,31 \%)$, and 'request for forgiveness' was spoken 4 times (2,31\%). The frequency of Indonesian players using Taking Responsibility strategy is 62 times. They expressed the strategy of Explicit Self-blame (ESB) 3 times in different situations. There are 30 utterances of Lack of Intent (LOI). There are 14 utterances $(8,1 \%)$ that belong to Expression of Self-deficiency. There is only one utterance of Refusal to Acknowledge Guilt (RAG) category used by Indonesian bridge players. Statement of the offense (STO) was used 4 times. An Explanation of the Situations (AES) was found 5 times. There are 38 utterances that belong to An Offer of Repair (AOR). There are three utterances $(1,73 \%)$ of Concern for the Hearer $(\mathrm{CFH})$ found in the data.

Meanwhile there are 146 apologies produced by Australian bridge players. There are 70 utterances of IFID. There are 42 utterances of 'an expression of regret'. There are 21 utterances of AOA. There are seven utterances which included a request for forgiveness. Explicit self-blame (ESB) was found four times. Lack of Intent (LOI) strategy was found eight times. There are 8 utterances included in the Expression of self-deficiency (ESD). There are four utterances included in the apology of the strategy to explain or account for the situation (AES). There are around 37 utterances that belong to An Offer of Repair (AOR). Promise for forbearance (POF) was spoken five times and Concern for the hearer ( $\mathrm{CFH}$ ) was used four times. There are 5 utterances of Underestimating the offense as Humor in the data. Table 1 below presents the frequency of apology strategies produced by both groups of respondents.

When comparing the data from both groups of respondents, we found some similarities of the apology strategies used by both groups. There are five types of apology strategies that are used with approximately similar frequencies. The first strategy is 'request for forgiveness'. The Indonesian bridge players produce four of this strategy, and the Australian produce seven of this. 
The following are two examples spoken by one of the Indonesian respondents.

Table 1 . The frequency of apology strategies produced by the Indonesian and Australian Bridge Players

\begin{tabular}{rlcccc}
\hline \multirow{2}{*}{ No. } & \multicolumn{1}{c}{ Strategies } & \multicolumn{3}{c}{ Indonesian } & \multicolumn{2}{c}{ Australian } \\
\cline { 3 - 6 } & & $\mathrm{N}$ & $\%$ & $\mathrm{~N}$ & $\%$ \\
\hline 1. & $\begin{array}{l}\text { Illocutionary Force } \\
\text { Indicating Devices } \\
\text { (IFID) }\end{array}$ & 74 & 42.8 & 70 & 48.0 \\
\hline 2. & $\begin{array}{l}\text { Taking of } \\
\text { Responsibility }\end{array}$ & 53 & 30.6 & 21 & 14.4 \\
\hline 3. & $\begin{array}{l}\text { An explanation or } \\
\text { account of the } \\
\text { situations (AES) }\end{array}$ & 5 & 2.9 & 4 & 2.7 \\
\hline
\end{tabular}

4. An offer of repair $\begin{array}{llll}38 & 22.0 & 37 & 25.4\end{array}$ (AOR)

5. Promise for $\quad \begin{array}{lllll}0 & 0 & 5 & 3.4\end{array}$ forbearance (POF)

$\begin{array}{llllll}\text { 6. Concern for the } & 3 & 1.7 & 4 & 2.7\end{array}$ hearer $(\mathrm{CFH})$

7. Underestimating the $\begin{array}{lllll}0 & 0 & 5 & 3.4\end{array}$ offense as Humor (UOH)

$\begin{array}{lllll}\text { Total } & 173 & 100 & 146 & 100\end{array}$

When comparing the data from both groups of respondents, we found some similarities of the apology strategies used by both groups. There are five types of apology strategies that are used with approximately similar frequencies. The first strategy is request for forgiveness. The Indonesian bridge players produce four of this strategy, and the Australian produce seven of this. The following are two examples spoken by one of the Indonesian respondents.

\section{(1) Yaelah, ternyata aku punya petanya dong. Maafkan hamba. (C3, ID)}

"Geez, it turns out I have the map. Forgive me."

This apology is a response for Situation 3. The respondent utters the apology Maafkan hamba that means "Forgive me" towards the hearer.
(2) Paman, maaf, tadi sepertinya beberapa badan mobil rusak. Saya benar-benar tidak sengaja. Tolong dimaafkan. (G4, ID)

"Uncle, I apologize, it seems like some car bodies were broken. I really didn't mean it. Please forgive me."

This apology contains the apology Tolong dimaafkan that means "Please forgive me". With this utterance the respondent, based on the provided situation, asked his uncle to forgive him for accidentally damaging his uncle's car.

To observe the similarity of the above apologies with those spoken by the Australian respondents, the following are three examples of requests for forgiveness produced by the Australian bridge players.

(3) Forgive me please, I forgot the book. (A8, AU)

The above apologetic utterance produced by an Australian respondent when responding to Situation 1. The respondent says "Forgive me, please" to his coach as he forgot to bring his coach's book that he is supposed to return at the time.

(4) Forgive me, it was my foolish. (B5, AU)

This is another example of the 'request for forgiveness' that is a response for Situation 2 which contains low offense.

(5) Forgive me, uncle. I'll repair it. The similar incidents won't happen again in the future. (G5, AU)

The above apology is a response for Situation 7 , in which the respondent borrowed his uncle's car, and he had an accident that damaged some parts of the car.

The second strategy that occurs relativey similar in terms of frequecy among the two respondent groups is explicit self-blame. This strategy is a sub-strategy of 'taking of responsibility'. Three such apologies accour among the Indonesian bridge players, and four occur among the Australian resondents. Below are the 'explicit self-blames' occured among the Indonesian respondents.

(6) Maaf, Pak/Bu, maaf, saya benar-benar minta maaf. Saya yang ceroboh, gak sengaja tumpah jadinya. Maaf ya, Pak/Bu. (B7, ID) 
"I apologize, Sir/Ma'am, I apologize, I really apologize. I was careless, I accidentally spilled it out. I apologize, Sir."

The above apology is uttered when a player spilled orange juice into his manager's trousers. He explicitly blamed himself for him being careless by saying saya yang ceroboh that means "I was careless".

(7) Mas/mba, saya mau mengakui salah saya. Mohon maaf sekali, layar laptopnya jadi hancur begini. Saya tadi nggak sengaja menyenggol laptopnya waktu mau angkat telepon. Kira-kira kalau saya bawa laptopnya ke tempat servis bagaimana mas/mba? insyaAllah semua biayanya biar saya yang tanggung. Maaf ya apabila jadi menyusahkan. (E1, ID)

\section{"Mas/mba, I want to admit that I have made a mistake. I really apologize, the laptop screen is broken like this. I accidentally nudged the laptop when I wanted to pick up the phone. What if I bring the laptop to the service station mas/mba? InsyaAllah, about all the costs let me be responsible. I apologize if it becomes troublesome."}

This explicit self-blame is an apology for Situation 5. This respondent explicitly utters saya mau mengakui salah saya that means "I want to admit that I have made a mistake" to show that he is responsible for damaging the hearer's laptop.

\section{(8) Maaf ya, Om. Aku kurang hati-hati banget emang. (G6, ID)}

"I apologize, Om. I'm really careless."

The above is the other explicit self-blame occuring among the Indonesian bridge players in response to Situation 7. The respondent uses the phrase Aku kurang hati-hati banget emang that means "I'm really careless" to show that what he did is out of his carelessness, and he feels responsible for the incident.

In the case of the Australian respondents uttering explicit self-blames, the following are two examples of such apologies.

(9) Sorry. I'm so careless. (B6, AU)
The above apology shows that the respondent admits his being not careful, spilling orange juice on his team manager's trousers.

(10) Oh, sorry. This is my fault. (F7, AU)

This explicit self-blame is an apology for spilling a bottle of milk on one's team mate's spotless car. The respondent blames himself as an expression of an apology.

Another strategy that is used among the two groups of respondents with fairly similar frequency is an explanation of the situations (AES). This strategy occurs five times ammong the Indonesian bridge and four times among the Australian bridge players. The following is one of such apologies uttered among the Indonesian respondents.

(11) Terima kasih, Paman, sudah meminjamkan mobilnya, dan saya minta maaf, Paman, saat perjalanan pulang tadi saya mengalami kecelakaan sehingga lampu utama mobil rusak dan bempernya bengkok. Besok biar saya benarkan di bengkel, Paman. (G2, ID)

"Thank you, Uncle, for lending me a car, and I apologize, Uncle, on the way home I had an accident so that the main headlights of the car were broken and the bumpers were bent.

Tomorrow I'll fix it in the workshop, Uncle."

The above apology is a response to Situation 5, in which the speaker damaged his uncle's car. In this example, the respondent explained that the car was broken because he had an accident while using the car. Interestingly, the expression saya mengalami kecelakaan that means "I had an accident" is also utterred in the other four apologies of this strategy.

With regards to the Australian bridge players, the following is one of the four explanations of the situations.

(12) I would explain carefully for what was happened to his car and ask for his forgiveness. (G2, AU)

The above apology is a response to Situation 7 , in which hypothetically the bridge player tells his uncle that his car has been damaged in several parts due to the accident experienced by the respondent.

The fourth strategy that occurs with the relatively similar frequency among both groups of 
respondents is an offer of repair (AOR). Among the Indonesian group this strategy occurs 38 times and 37 times among the Australian group. With this strategy a speaker offers refinements for the offences he committed, such as be responsible for the damage or paying compensations. The following are several of the strategy that occur among the Indonesian respondents.

(13) Maaf, Mas/Mba, saya lupa membawa buku bridge, mungkin bisa saya ambil dulu sekarang. (A8, ID)

"I apologize, Bro/Sis, I forgot to bring a bridge book, maybe I can take it now."

In this apology, the expression mungkin bisa saya ambil dulu sekarang that means "maybe I can take it now" is uttered because the speaker forgot to bring a book belonging to his coach. He offered to take the book to refine the violation he has committed that is he does not bring it.

(14) Ya Allah. Maaf, bro. Gak sengaja. Aku traktir jus jeruk lagi saja ya. (B3, ID)

"Oh my God. I apologize, Bro. I did not mean to. I'll treat you an orange juice again, okay?"

In this apology, the respondent offers to buy an orange juice for his manager because he has already spilled orange juice on his manager's trousers. This reaction is identified as an offer of repair as he attempts to make amends for what he has done.

(15)

\section{Maaf, Pak. Saya tidak sengaja, ini pak tisu untuk membersihkannya. (B5, ID)}

"I apologize, Sir. I accidentally. Here is some tissue to clean it, Sir."

The above is another an offer of repair, which is a response to Situation 2. The repair that is offered is handing out tissue or a napkin to clean the manager's trousers which are wet due to spilled orange juice.

(16) Maaf banget, kak. Saya tidak sengaja menjatuhkan laptop kakak. Nanti biar saya perbaiki laptop kakak agar supaya bisa digunakan kembali. (E2, ID)

"I apologize a lot, Kak. I accidentally dropped your laptop. Later, let me fix your laptop so that it can be used again."
The above apology is an offer of repair that is a response to Situation 5. In this situation, the speaker drops his senior's laptop, and he says that he will repair the laptop, so that it can be functional again.

(17) Maaf. Biar saya saja yang membersihkannya. (F2, ID)

"I apologize. Let me clean it up."

With this apology, the respondent offers to clean his partner's car after he spilled a bottle of milk in it (Situation 6). There are other 5 similar utterances that contain 'an offer of repair' in Situation 6.

(18) Paman, maaf sekali. Maaf, Paman. Biar aku bantu bawa ke bengkel ya.

"Uncle, I apologize. I apologize, uncle. Let me help take it to the workshop."

This apology is a response to Situation 7. The speaker apologies to the hearer after he damaged his uncle's car. In his apology he expresses that he will take his uncle's car to a workshop to be repaired. The offer of such compensation is also expressed by several other respondents; there are 6 utterances regarding Situation 7 that belong to this strategy.

\section{Maaf banget ini. Aku gak sengaja. Nanti aku transfer kerugiannya biar kamu bisa beli tas baru. (H3, ID)}

"I really apologize. I didn't mean it. I'll transfer money to you for the loss, so that later you can buy a new bag."

This offer of repair is an apology with regards to Situation 8. In this situation, the speaker has spilled black ink on a bag that belongs to another player. To apologize the speaker offers compensation so that the hearer can buy a new bag.

Such a strategy is also used among the Australian respondents in response to the given situations. This strategy is the second most frequently used strategy by Australian bridge players. As mentioned earlier, there are 37 offer of repair utterances found among this respondent group. The following are several examples of such a strategy among the Australian bridge players. 
(20) I'll say sorry and bring it back the next class. (A2, AU)

This apology contains 'an offer of repair' that is a response to Situation 1, in which a player does not bring his coach's book that he has promised to return it the time of the conversation.

(21) Oh really I would immediately wipe it with any tissues or anything there and say sorry. (B2, AU)

The above apologetic utterance is a response to a situation, in which the speaker just spilled orange juice on his team manager's trousers. The speaker says that he would make a repair by wiping the manager's wet trousers with tissues or other things available.

(22) I would apologize profusely (a lot), and I would insist on paying for the repairs for it. (E1, AU)

The above is another 'an offer of repair' strategy showing that the speaker would pay the repair fee of the probably damaged laptop of his senior. In this situation, the speaker dropped the laptop accidentally.

(23) Oh no, I'm sorry, should I wash your car? (F5, $\mathrm{AU})$

This apology is a response to a situation, in which the speaker spills a bottle of milk in his friend's car. The speaker, then, offers to wash the car as a repair for his action.

(24) I sincerely apologize. I won't do this kind of stupidity again. Let me fix it. (G9, AU)

This an offer of repair is a response to Situation 7, in which he apologizes to his uncle because he has damaged the car while he was borrowing it. In his apology, the speaker offers to repair the damage.

(25) I'm sorry. Should I buy a new bag for you? (H9, AU)

The above apology is a response to a situation, in which a bridge player just spilled black ink on a bag belonging to another player from another team. In his apology, the speaker offers to buy a new bag to repair his mistake of making the hearer's bag dirty.
The last apology strategy that occurs relatively similar in terms of frequency among the two respondent groups is concern for the hearer ( $\mathrm{CFH}$ ). With this strategy, the speaker gives attention to the hearer for the offence he made, such as the question "apakah anda baik-baik saja?' that means "are you alright?" Three of this strategy occur among the Indonesian bridge players, all of which are responses to Situation 4. Similarly, among the Australian group this strategy occur as responses to Situation 4, and this occur four times. The following is one example of the apology strategy that occurs among the Indonesian bridge players.

\section{(26) Maaf, maaf, nggak sengaja. Kamu gak apa-apa} kan?(D4, ID)

"I apologize, I didn't mean to. Are you okay?"

In the above apology, the speaker includes the expression/question kamu gak apa-apa kan? that is close in meaning to "Are you okay?". This strategy is a response to the situation when the respondent has just stepped on the toe of another player from another team. The question asked by the speaker above shows that he is concerned about the hearer's condition, especially his toe.

With regards, to the Australian respondent group, the four 'concerns for the hearer' are also the responses to Situation 4, in which the speaker accidentally has just treaded on another team player's toe in a closing ceremony of a bridge tournament. The following is one of the four apologies that belong to 'concern for the hearer' strategy.

(27) $\mathrm{Hi}$, are you okay? I'm sorry. (D7, AU)

This respondent starts his apology with the question "Hi, are you okay?", and this shows the speaker's concern about the hearer toe. With this question the speaker also genuinely wants to know whether or not he has hurt the hearer's toe.

Regarding to the level of offenses, both respondents preferred using the apology strategies of expression of regret, expression of self-deficiency, and concern for the hearer to the low level of offenses. Meanwhile, for the high level of offenses both groups preferred using the apology strategies of an offer of apology, request for forgiveness, an explanation of the situation, and an offer of repair. 
Some differences are also found among the two groups. There are three types of apology strategies used by Indonesian but were not used by the Australian group. They are self-dispraise, refusal to acknowledge guilt, and statement of the offense. On the other hand, there are also three types of apology strategies used by Australian but were not used by Indonesian. They are justify hearer, promise for forbearance, and underestimating the offense as humor. Also, Indonesian bridge players tend to use three types of apology strategies more often than Australian. Indonesian respondents more often used the apology strategies of an offer of apology, lack of intent, and expression of self-deficiency. Meanwhile, Australian respondents are more frequently to use the apology strategy of expression of regret than Indonesian respondents.

We can also see that, although both groups preferred using the strategy of 'illocutionary force indicating devices', Indonesian bridge players are more often to use 'an offer of apology' while the preferred strategy by Australian bridge players is 'an expression of regret'. Based on the level of offenses, the preferred apology strategy used by Indonesian bridge players in both levels is 'an offer of apology'. On the other hand, Australian bridge players mostly used the apology strategy of 'expression of regret' to the low level of offenses, and mostly used the strategy of 'an offer of repair' to the high level of offenses.

\section{CONCLUSION}

This research was undertaken by using a Discourse Completion Test (DCT) to elicit apologies from ten Indonesian bridge players and ten Australian bridge players. The research found that there are similarities and differences in apology strategies among the two respondent groups. Overall, 173 apology strategies by the Indonesian bridge players and 146 apology strategies by the Australian bridge players were collected, and they were classified based on the apology taxonomy proposed by Cohen and Olshtain (1981).
With these findings, this research is expected to provide additional knowledge of speech acts of apology used by two different speech communities with different cultures represented by the two respondent groups. However, it can be argued that the findings of this study cannot be generalized to all Indonesians and Australians. In addition, there are shortcomings as well as issues that have not been discussed with regards to other aspects of apology strategies, such as social relations between the speakers and hearers. Therefore, it is suggested that further research investigate or include these aspects.

\section{REFERENCES}

Austin, J. L. (1962). How to do things with words. London: Oxford University Press.

Blum-Kulka, S., \& Olshtain, E. (1984). Requests and Apologies: A Cross-Cultural Study of Speech Act Realization Patterns (CCSARP)1. Applied Linguistics, 5(3), 196-213. doi:10.1093/applin/5.3.196.

Bowe, H., Martin, K., \& Manns, H. (2014). Communication Across Cultures: Mutual understanding in a global world ( $2^{\text {nd }} \mathrm{ed}$.). Cambridge: Cambridge University Press.

Cohen, A. D., \& Olshtain, E. (1981). Developing A Measure of Sociocultural Competence: The Case Of Apology1. Language Learning, 31(1), 113-134. doi:10.1111/j.14671770.1981.tb01375.x.

Crystal, D. (2008). A Dictionary of Linguistics and Phonetics (6 ${ }^{\text {th }}$ ed.). Oxford: Blackwell.

Cutting, J. (2002). Pragmatics and Discourse: A Resource Book for Students. London: Routledge

Majeed, A., \& Janjua, F. (2014). Apology strategies and gender: A Pragmatic Study of apology speech acts in the Urdu language. Merit Research Journals, 2(3), 54-61. 
Mey, J. (2001). Pragmatics: An Introduction (2 ${ }^{\text {nd }}$ ed.). Oxford: Blackwell.

Morris, C. W. (1938). Foundations of the theory of signs (Vol. 1, Ser. 2). Chicago, IL: University of Chicago Press.

Murphy, J. (2015) Revisiting the apology as a speech act: The case of parliamentary apologies. Journal of Language and Politics, 14 (2). pp. 175-204.

Searle, J. R. (1969). Speech Acts. Cambridge: Cambridge University Press. doi:10.1017/ CBO9781139173438
Searle, J. R. (1976). A classification of illocutionary acts. Language in Society, 5(01), 1-23. doi:10.1017/s0047404500006837.

Shahrokhi, M., \& Jan, J. M. (2012). The realization of apology strategies among Persian males. Procedia - Social and Behavioral Sciences, 46, 692-700. doi:10.1016/j.sbspro.2012.05.183.

Subandi. (2014). Permintaan Maaf Dalam Bahasa Inggris Australia Dan Bahasa Indonesia: Sebuah Kajian Pragmatik Lintas Budaya Tentang Strategi Kesopanan Berbahasa. (Unpublished Master thesis). Universitas Gadjah Mada, Yogyakarta, Indonesia. 